\title{
REGULATION OF THE HUMAN SHORT TRANSIENT RECEPTOR POTENTIAL CHANNEL 3 (hTRP3) BY THE SERUM- AND GLUCOCORTICOID-INDUCED KINASE 1 (SGK1)
}

\author{
HAMDY M. EMBARK \\ Animal Physiology Department, Faculty of Vet. Medicine, South Valley University, Qena, Egypt
}

Received: 4 July 2016; $\quad$ Accepted: 9 August 2016

\begin{abstract}
The transient receptor potential channels (TRP channels) are widely expressed in a large number of various human and animal cell types. Most of the TRP channels are permeable for $\mathrm{Ca}^{2+}$ and some also for $\mathrm{Mg}^{2+}$. TRP channels are divided into three main groups based on their structure: short, long and osm-like TRPs. The short TRP subfamily of cation channels contains mammalian TRPs, TRPL, and the Drosophila TRP. The mammalian TRP superfamily of cation channels contains four subfamilies (TRP1; TRP4, 5; TRP2 and TRP3, 6, 7) based on sufficiently similar sequence and function. The human short transient receptor potential channel 3 (hTRP3) is expressed at the highest levels in brain, and at much lower levels in small intestine, colon, testis, prostate, ovary, placenta and lung. Cytosolic $\mathrm{Ca}^{2+}\left(\left[\mathrm{Ca}^{2+}\right]_{\mathrm{i}}\right)$ plays a crucial role in various cellular functions of virtually all cell types and is thus under tight hormonal control. However, cellular mechanisms governing the regulation of human TRP3 abundance in the cell membrane are poorly understood. Surface abundance of the epithelial $\mathrm{Na}^{+}$ channel is regulated by the Serum- and Glucocorticoid-Induced Kinase 1 (SGK1). The present study has been performed to explore whether human TRP3 is regulated by SGK1 and the related kinases SGK2, and SGK3. To this end, cRNA encoding human TRP3 (hTRP3) has been injected with or without cRNA encoding wild type SGK1, SGK2, and SGK3 into Xenopus Oocytes. In the presence of $\mathrm{Cl}^{-}$, hTRP3 mediated $\mathrm{Ca}^{2+}$ entry leads to secondary activation of $\mathrm{Ca}^{2+}$-sensitive $\mathrm{Cl}^{-}$channels $\left(\mathrm{I}_{\mathrm{Cl}(\mathrm{Ca})}\right)$. Coexpression of hTRP3 with SGK1 stimulates ( $\mathrm{I}_{\mathrm{Cl}(\mathrm{Ca})}$ ) but not by SGK2, and SGK3. The observations suggest that SGK1 regulate hTRP3 and are thus likely to participate in the regulation of calcium homeostasis.
\end{abstract}

Keywords: human TRP3, SGK isoforms, calcium homeostasis

\section{INTRODUCTION}

Calcium ions $\left(\mathrm{Ca}^{2+}\right)$ are essential for many physiological processes, including fertilization, muscle contraction, hormone secretion, immune responses, brain functions, cell growth and last but not least, apoptosis(Orreniuset al., 2003; Zhang et al., 2015). The signal transduction capacity of $\mathrm{Ca}^{2+}$ depends on the 10,000-fold gradient across the plasma membrane with $2.5 \mathrm{mM}$ extracellular and resting intracellular $\mathrm{Ca}^{2+}$ ion concentration of approximately $100 \mathrm{nM}$ (Clapham, 1995). Increased cytosolic free $\mathrm{Ca}^{2+}$ levels are interposed by either $\mathrm{Ca}^{2+}$ inflow across the plasma membrane by using different $\mathrm{Ca}^{2+}$ channels (Barrittet al., 2008) orrelease of $\mathrm{Ca}^{2+}$ from the internal $\mathrm{Ca}^{2+}$ stores such as the endoplasmic Reticulum (ER) (Parekh and Penner, 1997; Verkhratsky and Petersen, 2002).

Corresponding author:Dr.HAMDY M.EMBARK

E-mail address:h.embark@vet.svu.edu.eg

Present address: Animal Physiology Department, Faculty of Vet.

Medicine, South Valley University, Qena, Egypt
In mammals, $\mathrm{Ca}^{2+}$ concentration gradient between intracellular and extracellular fluids is tightly regulated by a complex homeostatic control mechanism involving fluxes of $\mathrm{Ca}^{2+}$ between theinterstitialfluid and the intestine, kidney, and bone (Mundy and Guise, 1999).The regulation of these fluxes islikely to come from more careful controlof three important hormones: thyrocalcitonin, parathyroid hormone (PTH), and Calcitriol (Boden and Kaplan, 1990). Several important cellular functions are dependent on the maintenance of the extracellular $\mathrm{Ca}^{2+}$ concentration within a very narrow range (Brown and MacLeod, 2001). Importantly, disturbances of this tightly controlled homeostatic system causesupsets inthe body's calcium metabolism that have expected effects, which can be attributed to effects on these cellular functions (Peacock, 2010).

Activation of the body's cells by hormones, neurotransmitters, and agents that stimulate the activity of the enzyme phospholipase C (PLC) leads to release of $\mathrm{Ca}^{2+}$ from distinct intracellular $\mathrm{Ca}^{2+}$ stores (Fan and Byron, 2000) and is followed by passive influx of $\mathrm{Ca}^{2+}$ from the extracellular space via a group of channels that have differently been 
referred to as $\mathrm{Ca}^{2+}$ release activated $\mathrm{Ca}^{2+}$ channels (CRAC), store operated $\mathrm{Ca}^{2+}$ channels (SOC), and receptor operated $\mathrm{Ca}^{2+}$ channels (ROC) (Hoth and Penner, 1992; Zweifach and Lewis, 1995).

These store-operated channels serve refilling of the $\mathrm{Ca}^{2+}$ store by providing a $\mathrm{Ca}^{2+}$ entry pathway and may in addition control cell membrane potential and homeostasis of monovalent cations (Parekh and Penner, 1997). Because $\mathrm{Ca}^{2+}$ entering the cell replenishes the intracellular $\mathrm{Ca}^{2+}$ stores that act likes capacitors, it has also been called "CapacitativeCa ${ }^{2+}$ Entry, (CCE)" or "Store-Operated $\mathrm{Ca}^{2+}$ Entry, (SOCE)" (Putney, 1990).Transient Receptor Potential (TRP) ion channels or TRPs are thought to mediate CCE or SOCE (Montell, 1997).

TRPsare the largest group of non-selective and polymodalcation channels which pass $\mathrm{Ca}^{2+}$ (and other cations too) into the cell down its electrochemical gradient in response to different stimuli, thereby increasing the intracellular $\mathrm{Ca}^{2+}$ concentration and causing cell depolarization (Kumar et al., 2014). TRP channels were first described in the fruit flyDrosophila melanogasteras a phototransductiontrpmutant associated with a defect in light-induced calcium entry and a modified response to light (Minke, 1977; Hardie and Minke, 1992). Subsequently members of the TRP family have been identified in vertebrates, and other invertebrates, and in lower eukaryotes such as yeast and fungi. However, so far TRPs or their exact homologs have not been detected in plants (Kumar et al., 2014).

TRPs are classified on the basis of their sequence homology and by the presence of specific signature domains and motifs such as the TRP-domain, TRPbox motifs, ankyrin repeats, etc. (Clapham, 2003). Based on amino acid sequence, homology with other TRP channels, and the presence of specific structural features, the Drosophila TRPshave been divided into seven subfamilies, namely, TRPC (Canoical or Classical), TRPV (Vanilloid-like), TRPM (Melastatin-like), TRPA (Ankyrin), TRPP (Polycystin), TRPML (Mucolipin) and TRPN (No Mechanoreceptor Potential C, NOMPC) (Nilius and Owsianik, 2011). However, the mammalian TRPs have been divided into six subfamilies (the TRPN family does not appear in mammals) (Hartenecket al., 2000; Montell, 2005).

In mammals, TRP channels are ubiquitously expressed in almost all cell types and tissues, albeit at different levels (Kumar et al., 2014). Most of the TRPs are selectively activated by specific ligands and are polymodal in nature (Baez-Nieto, et al., 2011). TRP channels are regulated by multiple stimuli, both physical and chemical and a few members of TRPs are thermosensitive. The complex polymodalregulation of TRP channels by intracellular as well as extracellular components such as, $\mathrm{pH}$, interacting proteins, etc. and the multiple routs of regulation by phosphorylation-dephosphorylation, suggest that these channels integrate multiple signaling events at the plasma membrane (Kumar et al., 2014).

Seven mammalian TRPC channels have been isolated, which are further subdivided by sequence and function into four groups: TRPC1, TRPC2, TRPC3/6/7, and TRPC4/5 (Vazquez, et al., 2004; Liao et al., 2014), although it has been suggested that TRPC1 is dissimilar enough from TRPC4 and TRPC5 that it should comprise its own fourth group (Montell, 2005). All TRPC homologs studied were widely expressed within the central nervous system (CNS) and expression in peripheralnervous system (PNS)was often observed. In spite of this, each type of channel exhibited a different distribution profile (Riccioet al., 2002).

Human TRP3is highly expressed in CNS and smooth and cardiac muscle cells, and likely to play a role in both excitable as well as non-excitable cells, being potentially involved in a wide spectrum of $\mathrm{Ca}^{2+}$ signalling mechanisms ( $\mathrm{Li}$ et al., 1999). TRP3 shows multiple potential sites for regulatory phosphorylation in both amino and carboxy termini located in the cytoplasm (Eder et al., 2007). Interactions between different protein-interacting domains in TRP3 channels and a variety of regulatory proteins have been identified that are apparently essential for correct targeting or activation of TRP3 channels (Sinkinset al., 2004).

The Serum- and glucocorticoid-induced protein kinase, SGK (denoted as SGK1), was identified as a novel serine/threonine protein kinase under transcriptional control by serum and glucocorticoids (Webster et al., 1993). The SGK1 gene encodes a 50 $\mathrm{kDa}$ protein that is a member of the "AGC" family of serine/threonine protein kinases that includes protein kinases A (PKA),G (PKG), andC (PKC)(Bruhn et al., 2010). SGK1 has two other protein homologues (SGK2 and SGK3), and there are four SGK1 isoforms that are products of alternate translation initiation and can localize to a variety of cellular compartments (Arteagaet al., 2007).

SGK1 is a ubiquitously expressed serine-threonine kinase, highly expressed in the nervous system, playing an important physiological role in CNS in which it regulates different ion channels (Weschet al., 2010). SGK1 has previously been shown to regulate a wide variety of carriers and ion channels (Lang et al., 2006), including the epithelial $\mathrm{Ca}^{2+}$ channels TRPV5 (Embark et al., 2004) and TRPV6 (Sopjaniet al., 2010).Furthermore, SGK1 participates in the regulation of renal tubular $\mathrm{Na}^{+}$reabsorption, salt appetite, and thus blood pressure by regulation of renal epithelial $\mathrm{Na}^{+}$channel $(\mathrm{ENaC})$ (Chen et al., 
1999).

SGK1 transcription is stimulated by increase in cytosolic $\mathrm{Ca}^{2+}$ activity $\left[\mathrm{Ca}^{2+}\right]_{\mathrm{i}}$ (Lang and Stournaras, 2013). SGK1 has been shown to be critically important for the $\mathrm{Ca}^{2+}$ entry into mast cells after activation of the IgE receptor (Sobiesiaket al., 2009), an effect mediated by regulation of $\mathrm{Ca}^{2+}$ channel 1 (ㅁAI Calcium Release- $\underline{\text { Activated Calcium }}$ Modulator 1(Orai1)/ Stromal interaction molecule 1 (STIM1)) (Eylensteinet al., 2011). Recent observations revealed a powerful effect of the SGK1 on Orail abundance, SOCE, activation and function of platelets (Borstet al., 2012).

Interestingly, SGK contains a proline rich region (PXXP motif, where $\mathrm{x}$ denotes any amino acid) in its amino terminal regulatory domainand another protein interaction motif called PDZ domain in its carboxy terminal (O'Keeffe et al., 2013).SGK1 includes three such PXXP motifs which could be involved in protein-protein interactions withproteins containing tryptophan-rich WW motif and thereby potentially modulate its activity (Zhou and Snyder, 2005). The name PDZ is derived from the first three proteins in which these domains were identified: PSD-95 (a 95 $\mathrm{kDa}$ protein involved in signaling at the post-synaptic density), DLG (the Drosophila melanogaster Discs Large protein) and ZO-1 (the zonulaoccludens 1 protein involved in maintenance of epithelial polarity) (Harris and Lim, 2001).

The aim of the current study was to investigate whether hTRP3 is regulated by SGK1 and/or the closely related isoforms SGK2, and SGK3. To this end, cRNA encoding wild-type hTRP3 has been injected into Xenopus oocytes with or without additional injection of cRNA encoding wild-type SGK1, SGK2, and SGK3. The experiments described here were performed by measuring ionic currents from Xenopus oocytes stably expressing hTRP3 using the two-electrode voltage-clamp technique.

\section{MATERIALS AND METHODS}

\section{Molecular biology}

Plasmid DNA of the human wild-type TRP3 (Zhu et al., 1996; Zhu et al., 1998), of human wild-type SGK1 (Waldeggeret al., 1997), human wildtypeSGK2 (Kobayashi et al., 1999) and human wildtype SGK3 (Kobayashi et al., 1999) were linearized with NotI(Source: Nocardiaotitidis bacteria) and transcribed in vitro with $\mathrm{T} 7 \mathrm{RNA}$ polymerase in the presence of the cap analog $\mathrm{m}^{7} \mathrm{G}\left(5^{\prime}\right) \mathrm{ppp}\left(5^{\prime}\right) \mathrm{G}$ at a concentrationof $1 \mathrm{mM}$.TemplatecDNAwasremovedby digestionwithRNase-freeDNaseI.Thecomplementary RNA (cRNA) was purified by phenol/chloroform extraction followed by precipitation with 0.5 volumes $7.5 \mathrm{M}$ ammonium acetate and 2.5 volumes of ethanol to remove unincorporated nucleotides. The integrity of the transcripts was checked by denaturing agarose gel electrophoresis. The complete constructs were sequenced to prove the correct nucleotide exchange and to exclude any additional mutations.

\section{Expression in Xenopus laevis oocytes}

StagesV and VI oocytes were harvested from female wild type Xenopuslaevis (Knysna, Rep. South Africa) using previously described procedures (Wagner et al., 2000). Briefly, frogs were anaesthetized by immersion in $0.1 \%$ 3-aminobenzoic acid ethyl ester in water. Small pieces of ovary were removed and the incision sutured. Frogs were placed in shallow water until full recovery of reflexes, and subsequently released into the tank. Oocytes were injected with 20ng/25nlcRNA of hTRP3 using a microinjection device (Bachofer, Reutlingen, Germany).In a second step, the oocytes were injected with $25 \mathrm{nl}$ water, as a control, or with $7.5 \mathrm{ng} / 25 \mathrm{nl}$ water cRNA ofwild type kinases (SGK1, SGK2, and SGK3). All experiments were performed at room temperature $\left(20-24{ }^{\circ} \mathrm{C}\right) 2-3$ days after injection of the respective cRNAs.

\section{Voltage-clamp analysis}

In two-electrode voltage-clamp experiments, currents were recorded during a 5-s linear voltage ramp from $150 \mathrm{mV}$ to $+50 \mathrm{mV}$. The intermediate holding potential between the voltage ramps was $-50 \mathrm{mV}$. Data were filtered at $10 \mathrm{~Hz}$ and recorded with MacLab digital to analog converter and software for data acquisition and analysis (ADInstruments, Castle Hill, Australia). The bath solution contained 96 $\mathrm{mMNaCl}, 2 \mathrm{mMKCl}, 1 \mathrm{mM} \mathrm{MgCl}_{2}, 1 \mathrm{mM} \mathrm{BaCl}_{2}, 10$ $\mu \mathrm{M}$ methoxyverapamil, $5 \mathrm{mM}$ HEPES, $\mathrm{pH} 7.4$ with or without $10 \mathrm{mM} \mathrm{CaCl} 2$. Oocytes were kept in modified Barth's solution containing $88 \mathrm{mMNaCl}, 1$ mMKCl, $2.4 \mathrm{mM} \mathrm{NaHCO}$, $0.8 \mathrm{mM} \mathrm{MgSO}$, 0.3 $\mathrm{mMCa}\left(\mathrm{NO}_{3}\right)_{2}, 0.4 \mathrm{mM} \mathrm{CaCl}{ }_{2}$ and $5 \mathrm{mM}$ HEPES, $\mathrm{pH}$ 7.4 supplemented with $25 \mu \mathrm{g} / \mathrm{ml}$ gentamycin. The final solutions were titrated to the $\mathrm{pH}$ indicated using $\mathrm{HCl}$ or $\mathrm{NaOH}$. The flow rate of the superfusion was $20 \mathrm{ml} / \mathrm{min}$ and a complete exchange of the bath solution was reached within about $10 \mathrm{~s}$. For determination of $\mathrm{Ca}^{2+}$ currents $\left(\mathrm{I}_{\mathrm{Ca}}\right)$, the experiments were performed with $\mathrm{Cl}^{-}$depleted oocytes (bathed for 24 hours in $\mathrm{Cl}$ - free medium) in the absence of extracellular $\mathrm{Cl}^{-}$in the bath and $\mathrm{KCl}(3 \mathrm{M})$ filled agar bridges were used as reference electrodes to minimize liquid junction potentials. In the presence of $\mathrm{Cl}^{-}$and absence of $\mathrm{Cl}^{-}$channel inhibitors, the addition of 10 $\mathrm{mM} \mathrm{CaCl} 2$ induced an inward current $\left(\mathrm{I}_{\mathrm{Cl}(\mathrm{Ca})}\right)$ which was created by entry of $\mathrm{Ca}^{2+}$ and subsequent activation of $\mathrm{Ca}^{2+}$ sensitive $\mathrm{Cl}^{-}$channels (Hoenderopet al., 1999b; Machaca and Hartzell, 1999). The peak inward current was taken as a measure for hTRP3 activity. $\mathrm{I}_{\mathrm{Cl}(\mathrm{Ca})}$ activity is synchronously triggered by the intracellular calcium concentration close to the membrane determined by hTRP3. Thus, $\mathrm{I}_{\mathrm{Cl}(\mathrm{Ca})}$ activity mirrors activation and inactivation kinetics of hTRP3(Miledi and Parker, 1984). Expression and currents may vary from batch to batch. Thus, care was taken to make comparisons 
always within batches.

\section{Statistical analysis}

Data are expressed as mean \pm s.e.m., where $n$ is the number of oocytes investigated. All experiments were repeated with at least 3 batches of oocytes; in all repetitions qualitatively similar data were obtained. All data were tested for significance using paired or unpaired Student'st-test, and only results with $P<$ 0.05 were considered as statistically significant. The statistical software Origin 8.1 (OriginLab Corp., Northampton, MA) was used to perform all statistical analyses.

\section{RESULTS}

Activation of $\mathrm{Ca}^{2+}$ sensitive $\mathrm{Cl}^{-}$channelsin hTRP3expressing oocytes by cell membrane hyperpolarization.

The current was observed with Xenopus oocytes at 2 days after the injection of hTRP3 cRNA. In hTRP3expressing oocytes, $\mathrm{Ca}^{2+}$ entry through hTRP3 triggered a hyperpolarization-activated inward current by activation of $\mathrm{Ca}^{2+}$ sensitive $\mathrm{Cl}^{-}$channels $\left(\mathrm{I}_{\mathrm{Cl}(\mathrm{Ca})}\right)$ (Fig. 1B). Addition of $10 \mathrm{mM} \mathrm{CaCl} 2$ significantly increased this current (Fig. 1B).
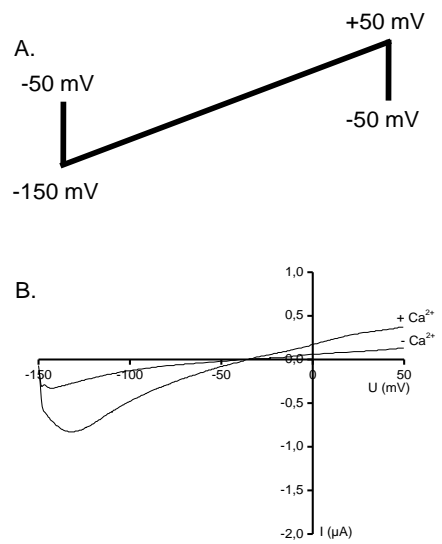

Fig. 1.hTRP3 mediated calcium currents indirectly activate an endogenous chloride conductance $\left(\mathrm{I}_{\mathrm{Cl}(\mathrm{Ca})}\right)$. A: The cartoon at the top shows the applied twoelectrode voltage-clamp protocol. B: Representive original voltage-clamp recording to $\mathrm{Ca}^{2+}$ induced $\mathrm{Cl}^{-}$ current $\left(\mathrm{I}_{\mathrm{Cl}(\mathrm{Ca})}\right)$ from hTRP3-expressing oocytes elicited by linear voltage ramp from $-150 \mathrm{mV}$ to +50 $\mathrm{mV}$ delivered at $5 \mathrm{sec}$ intervals from a holding potential of $-50 \mathrm{mV}$. Currents were recorded in the presence and absence of $10 \mathrm{mM} \mathrm{CaCl}_{2}$.

\section{Stimulation of $\mathrm{Ca}^{2+}$ induced current by SGK1 in Xenopus oocytes}

In the presence of $\mathrm{Cl}^{-}$the $\mathrm{Ca}^{2+}$ entry through hTRP3 stimulated $\mathrm{Ca}^{2+}$ sensitive $\mathrm{Cl}^{-}$channels leading to the appearance of a large $\mathrm{Cl}^{-}$current $\left(\mathrm{I}_{\mathrm{Cl}(\mathrm{Ca})}\right)$. As shown in
Fig. 2, $10 \mathrm{mMCa}^{2+}$ triggered a rapidly activating, slowly and partially inactivating inward current in hTRP3 expressing oocytes with additional expression of SGK1.

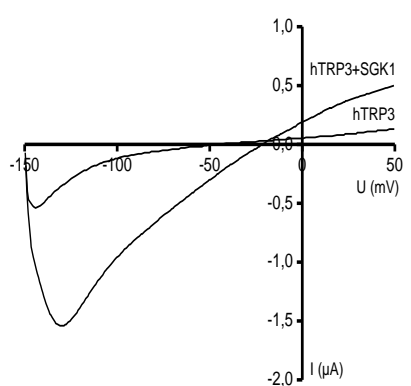

Fig. 2. Stimulation of the $\mathrm{Ca}^{2+}$ induced $\mathrm{Cl}^{-}$current $\left(\mathrm{I}_{\mathrm{Cl}(\mathrm{Ca})}\right)$ in Xenopus oocytes by the combined expression of hTRP3 and SGK1. Current-voltage $(I / V)$ relationships of mean peak currents from Xenopus oocytes before and after application of 10 $\mathrm{mM} \mathrm{CaCl}{ }_{2}$.

Effect of SGK2 and SGK3 on hTRP3 mediated currents in Xenopus oocytes

Further studies have been performed to determine the influence of SGK2 and SGK3 on hTRP3 mediated currents. The peak inward current was taken as a measure for hTRP3 activity. As reported earlier, the entry of $\mathrm{Ca}^{2+}$ triggers $\mathrm{Ca}^{2+}$ sensitive $\mathrm{Cl}^{-}$channels (Miledi and Parker, 1984). As shown in figure 3, coexpression of hTRP3 together with SGK1 led to a significant increase of the current induced by addition of $10 \mathrm{mM} \mathrm{CaCl} 2$. In contrast, the current was not increased by coexpression of hTRP3 with either SGK2 or SGK3.

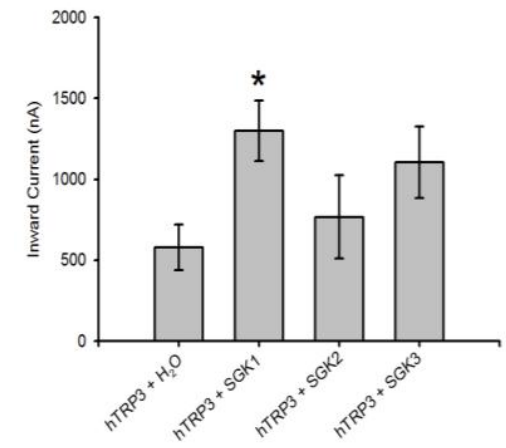

Fig. 3. Stimulation of the $\mathrm{Ca}^{2+}$ induced $\mathrm{Cl}^{-}$current $\left(\mathrm{I}_{\mathrm{Cl}(\mathrm{Ca})}\right)$ in Xenopus oocytes by the combined expression of hTRP3, SGK1 but not with SGK2 or SGK3. Bar graphs showing the mean peak inward current of hTRP3-expressing oocytes after application of $10 \mathrm{mM} \mathrm{CaCl}$. Arithmetic means \pm SEM. * indicates significant difference, $(* \mathrm{p}<0.05)$. 


\section{DISCUSSION}

The primary objective of the current study was to explore the impacts of serum- and glucocorticoidinduced kinases SGK1, SGK2, and SGK3 on hTRP3 $\mathrm{Ca}^{2+}$ channel activity.This investigation reveals a powerful effect of the serum- and glucocorticoidinduced kinase SGK1 on SOCE and discloses a completely novel signaling mechanism in the regulation of hTRP3 $\mathrm{Ca}^{2+}$ channel activity. This activity has obvious significantinduction by using SGK1, but not by SGK2 or SGK3.The effect of SGK1 on hTRP3 channel activity requires an intact catalytic subunit, wild-type SGK1(Kobayashi and Cohen, 1999;Boehmeret al., 2003).

Importantly, the present investigation reveals that expression of hTRP3 $\mathrm{Ca}^{2+}$ channels induces a $\mathrm{Ca}^{2+}$ entry allowing theintracellular accumulation ofCa ${ }^{2+}$ and generating a $\mathrm{Ca}^{2+}$ inward current. In the presence of $\mathrm{Cl}^{-}, \mathrm{Ca}^{2+}$ influx through hTRP3 $\mathrm{Ca}^{2+}$ channels generates further $\mathrm{Cl}^{-}$inward currents (Hoenderop et al, 1999a) by activation of endogenous $\mathrm{Ca}^{2+}$ activated $\mathrm{Cl}^{-}$channels in Xenopus oocytes (Callamaras and Parker, 2000).

SGK1 expression is upregulated by glucocorticoids (Webster et al., 1993), aldosterone (Cowling and Birnboim, 2000), cell shrinkage (Waldeggeret al., 1997) and by a wide range of other factors (Lang and Cohen, 2001). Notably, SGK1 is under transcriptional control of $\mathrm{Ca}^{2+}$ ions inside the cells (Brickleyet al., 2013) and is thus likely to participate in the regulation of calcium homeostasis by regulation of differentcation channels including hTRP3 channels.

SGK1 has previously been shown to compromise $\mathrm{Ca}^{2+}$ influx into cells by regulating different $\mathrm{Ca}^{2+}$. permeable TRP channels such as TRPV5 (Palmadaet al., 2005) and TRPV6 (Bohmeret al., 2007). Moreover, SGK1 contributes to regulation ofthe epithelial $\mathrm{Na}^{+} / \mathrm{H}^{+}$exchanger NHE3 (Yun et al., 2002a) and a wide variety of $\mathrm{K}^{+}$channels (Lauferet al., 2009; Lang et al., 2009) such as the voltage gated $\mathrm{K}^{+}$channel Kv1.3 (Gamperet al., 2002) and the renal epithelial $\mathrm{K}^{+}$channel ROMK1 (Yun et al., 2002b).

Activation of $\mathrm{K}^{+}$and $\mathrm{Ca}^{2+}$ channels is expected to hyperpolarize the cell membrane and thus enhance the driving force for $\mathrm{Ca}^{2+}$ entry through several $\mathrm{Ca}^{2+}$ channels. SGK1 expression (Klingelet al., 2000; Tarunoet al., 2008) and activity (Imai et al., 2003) are stimulated by increased cytosolic $\mathrm{Ca}^{2+}$ activity. Thus, at least in theory, SGK1 could serve as an amplifier of $\mathrm{Ca}^{2+}$ entry leading to induction of $\mathrm{Ca}^{2+}$ channel Orai1/STIM1 (Eylensteinet al., 2011) and hTRP3 channels activity (Fig. 4).

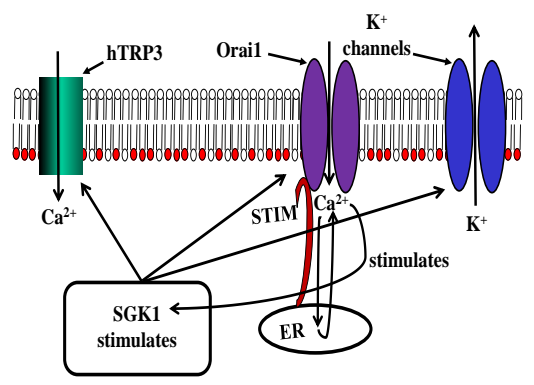

Fig. 4.Scheme illustrating the SGK1-sensitive regulation of hTRP3 channel activity. SGK1 participates in the regulation of transport proteins in plasma membrane, such as $\mathrm{K}^{+}$and Orai1/STIM1 channels, which have been shown to be SGK1 targets in different cell types.

Further experimental studies are required to confirm a potentially regulatory effect of SGK1 on hTRP3 channel activity. Theseexperiments will be needed to provide detailed information about the molecular mechanism behind SGK1-dependent regulation of hTRP3 channel activity.

\section{CONCLUSIONS}

In conclusion, the present observations identify hTRP3as a target of a regulatory mechanism involving the serine/threonine kinase. The SGK1 is a novel transcriptional and powerful regulator of hTRP3 which is at least partially effective through activation of $\mathrm{Ca}^{2+}$ entry as well as channel activity. Thus, SGK1-dependent hTRP3 regulations can influence SOCE and activation-dependent $\mathrm{Ca}^{2+}$ entry as well as $\mathrm{Ca}^{2+}$-dependent mechanisms in brain, heart, and smooth muscle cells.

\section{ACKNOWLEDGEMENTS}

The authorgratefully acknowledges all members and professors of the Department of Animal Physiology, Faculty of Veterinary Medicine, South Valley University, Qena, Egypt and of Physiology Institute, Faculty of Medicine, EberhardKarls University, Tuebingen, Germany, where the present work was performed, for their constant encouragement and kind help.

\section{REFERENCES}

Arteaga, M.F.; Alvarez de la Rosa, D.; Alvarez, J.A. and Canessa, C.M. (2007): Multiple translational isoforms give functional specificity to serum- and glucocorticoidinduced kinase 1. Mol. Biol. Cell. 18, 20722080.

Baez-Nieto, D.; Castillo, J.P.;Dragicevic, C.; Alvarez, O. and Latorre, R. (2011): Thermo- 
TRP channels: biophysics of polymodal receptors. Adv. Exp. Med. Biol. 704, 469-490.

Barritt, G.J.; Chen, J. and Rychkov, G.Y. (2008): $\mathrm{Ca}^{2+}$-permeable channels in the hepatocyte plasma membrane and their roles in hepatocyte physiology. Biochim.Biophys.Acta. 1783, 651-672.

Boden, S.D. and Kaplan, F.S. (1990): Calcium homeostasis. Orthop.Clin.North. Am. 21, 3142.

Boehmer, C.; Henke, G.;Schniepp, R.;Palmada, M.; Rothstein, J.D.;Broer, S. and Lang, F. (2003): Regulation of the glutamate transporter EAAT1 by the ubiquitin ligase Nedd4-2 and the serum and glucocorticoid-inducible kinase isoforms SGK1/3 and protein kinase B. J. Neurochem. 86, 1181-1188.

Bohmer, C.; Palmada, M.; Kenngott, C.; Lindner, R.; Klaus, F.; Laufer, $J$. and Lang, $F$. (2007):Regulation of the epithelial calcium channel TRPV6 by the serum and glucocorticoid inducible kinase isoforms SGK1 and SGK3. FEBS. Lett. 581, 55865590.

Borst, O.; Schmidt, E.M.; Munzer, P.; Schonberger, T.; Towhid, S.T.; Elvers, M.; Leibrock, C.; Schmid, E.; Eylenstein, A.; Kuhl, D.; May, A.E.; Gawaz, M. and Lang, F. (2012):The serum- and glucocorticoid-inducible kinase 1 (SGK1) influences platelet calcium signaling and function by regulation of Orai 1 expression in megakaryocytes. Blood. 119, 251-261.

Brickley, D.R.;Agyeman, A.S.; Kopp, R.F.; Hall, B.A.; Harbeck, M.C.;Belova, L.;Volden, P.A.; Wu, W.; Roe, M.W. and Conzen, S.D. (2013): Serum- and glucocorticoid-induced protein kinase 1 (SGK1) is regulated by store-operated $\mathrm{Ca}^{2+}$ entry and mediates cytoprotection against necrotic cell death. J. Biol. Chem. 288, 3270832719.

Brown, E.M. and MacLeod, R.J. (2001): Extracellular calcium sensing and extracellular calcium signaling. Physiol. Rev. 81, 239-297.

Bruhn, M.A.; Pearson, R.B.;Hannan, R.D. and Sheppard, K.E. (2010): Second AKT: the rise of SGK in cancer signaling. Growth Factors. 28, 394-408.

Callamaras, N. and Parker, I. (2000): $\mathrm{Ca}^{2+}$ dependent activation of $\mathrm{Cl}^{-}$currents in Xenopus oocytes is modulated by voltage. Am. J. Physiol. Cell. Physiol. 278, C667-C675.

Chen, S.Y.;Bhargava, A.;Mastroberardino, L.; Meijer, O.C.; Wang, J.;Buse, P.; Firestone, G.L.;Verrey, F. and Pearce, D. (1999): Epithelial sodium channel regulated by aldosterone-induced protein sgk. Proc. Natl. Acad. Sci. U. S. A. 96, 2514-2519.

Clapham, D.E. (1995): Calcium signaling. Cell. 80, 259-268.

Clapham, D.E. (2003): TRP channels as cellular sensors. Nature. 426, 517-524.
Cowling, R.T. and Birnboim, H.C. (2000): Expression of serum- and glucocorticoid-regulated kinase (sgk) mRNA is up-regulated by GM-CSF and other proinflammatory mediators in human granulocytes. J. Leukoc. Biol. 67, 240-248.

Eder, P.;Poteser, M. and Groschner, K. (2007): TRPC3: a multifunctional, pore-forming signalling molecule. HandbExpPharmacol. 179, 77-92.

Embark, H.M.;Setiawan, I.;Poppendieck, S.; van de Graaf, S.F.;Boehmer, C.;Palmada, M.;Wieder, T.;Gerstberger, R.; Cohen, P.; Yun, C.C.;Bindels, R.J. and Lang, F. (2004): Regulation of the epithelial $\mathrm{Ca}^{2+}$ channel TRPV5 by the NHE regulating factor NHERF2 and the serum and glucocorticoid inducible kinase isoforms SGK1 and SGK3 expressed in Xenopus oocytes. Cell. Physiol. Biochem. 14, 203-212.

Eylenstein, A.;Gehring, E.M.;Heise, N.;Shumilina, E.; Schmidt, S.;Szteyn, K.;Münzer, P.;Nurbaeva, M.K.;Eichenmüller, M.;Tyan, L.; Regel, I.;Föller, M.;Kuhl, D.;Soboloff, J.;Penner, R. and Lang, F. (2011): Stimulation of $\mathrm{Ca}^{2+}$-channel Orai1/STIM1 by serum and glucocorticoid-inducible kinase 1 (SGK1). FASEB J. 25, 2012-2021.

Fan, J.1.and Byron, K.L. (2000): $\mathrm{Ca}^{2+}$ signalling in rat vascular smooth muscle cells: a role for protein kinase $\mathrm{C}$ at physiological vasoconstrictor concentrations of vasopressin. J Physiol. 524, 821-831.

Gamper, N.;Fillon, S.;Feng, Y.; Friedrich, B.; Lang, P.A.; Henke, G.; Huber, S.M.; Kobayashi, T.; Cohen, P. and Lang, F. (2002): $\mathrm{K}^{+}$channel activation by all three isoforms of serum- and glucocorticoid-dependent protein kinase SGK. Pflugers Arch. 445, 60-66.

Hardie, R.C. and Minke, B. (1992): The trp gene is essential for a light-activated $\mathrm{Ca}^{2+}$ channel in Drosophila photoreceptors. Neuron. 8, 643651

Harris, B.Z. and Lim, W.A. (2001): Mechanism and role of PDZ domains in signaling complex assembly. J. Cell. Sci. 114, 3219-31.

Harteneck, C.; Plant, T. and Schultz, G. (2000): From worm to man: three subfamilies of TRP channels. Trends Neurosci. 23, 159-166.

Hoenderop, J.G.; Van Der Kemp, A.W.;Hartog, A.; van Os, C.H.;Willems, P.H. and Bindels, R.J. (1999a): The epithelial calcium channel, $\mathrm{ECaC}$, is activated by hyperpolarization and regulated by cytosolic calcium. Biochem.Biophys. Res. Commun. 261, 488492.

Hoenderop, J.G.; Van Der Kemp, A.W.;Hartog, A.; van de Graaf, S.F.; van Os, C.H.;Willems, P.H. and Bindels, R.J. (1999b): Molecular identification of the apical $\mathrm{Ca}^{2+}$ channel in 1 , 25dihydroxyvitamin D3-responsive epithelia. J. Biol. Chem. 274, 8375-8378. 
Hoth, M. and Penner, R. (1992): Depletion of intracellular calcium stores activates a calcium current in mast cells Nature. 355, 353-356.

Imai, S.; Okayama, N.; Shimizu, M. and Itoh, M. (2003): Increased intracellular calcium activates serum and glucocorticoid-inducible kinase 1 (SGK1) through a calmodulincalcium calmodulin dependent kinase pathway in Chinese hamster ovary cells. Life Sci. 72, 2199-2209

Klingel, K.; Warntges, S.; Bock, J.; Wagner, C.A.; Sauter, M.; Waldegger, S.; Kandolf, R. and Lang, F. (2000):Expression of cell volumeregulated kinase h-sgk in pancreatic tissue. Am. J. Physiol. Gastrointest. Liver Physiol. 279, G998-G1002

Kobayashi, T. and Cohen, P. (1999): Activation of serum- and glucocorticoid-regulated protein kinase by agonists that activate phosphatidylinositide 3-kinase is mediated by 3phosphoinositide-dependent protein kinase-1 (PDK1) and PDK2. Biochem. J. 339, 319-328.

Kobayashi, T.;Deak, M.;Morrice, N. and Cohen, P. (1999): Characterization of the structure and regulation of two novel isoforms of serumand glucocorticoid-induced protein kinase. Biochem J. 344, 189-197.

Kumar, A.;Kumari, S.;Majhi, R.K.; Swain, N.;Yadav, M. andGoswami, C. (2014): Regulation of TRP channels by steroids: Implications in physiology and diseases. Gen. Comp. Endocrinol. [Epub ahead of print].

Lang, F.;Artunc, F. and Vallon, V. (2009): The physiological impact of the serum and glucocorticoid-inducible kinase SGK1. Curr.Opin.Nephrol.Hypertens. 18, 439-448.

Lang, F. and Cohen, P. (2001): Regulation and physiological roles of serum- and glucocorticoid induced protein kinase isoforms. Sci. STKE 2001, RE17.

Lang, F.;Bohmer, C.;Palmada, M.;Seebohm, G.;Strutz-Seebohm, N. and Vallon, V. (2006): (Patho) physiological significance of the serum- and glucocorticoid-inducible kinase isoforms. Physiol. Rev. 86, 1151-1178.

Lang, F. and Stournaras, C. (2013): Serum and glucocorticoid inducible kinase, metabolic syndrome, inflammation, and tumor growth. Hormones (Athens). 12, 160-171.

Laufer, J.; Boehmer, C.; Jeyaraj, S.; Knuwer, M.; Klaus, F.; Lindner, R.; Palmada, M. and Lang, F. (2009):The C-terminal PDZ-binding motif in the Kv1.5 potassium channel governs its modulation by the $\mathrm{Na}^{+} / \mathrm{H}^{+}$exchanger regulatory factor 2.Cell. Physiol. Biochem. 23, 25-36

Li, H.S.;Xu, X.Z. andMontell, C. (1999): Activation of a TRPC3-dependent cation current through the neurotrophin BDNF. Neuron 24, 261-273.

Liao, Y.; Abramowitz, J. and Birnbaumer, L. (2014): The TRPC family of TRP channels: Roles inferred (mostly) from knockout mice and relationship to ORAI proteins. Handb. Exp. Pharmacol. 223, 1055-1075.

Machaca, K. and Hartzell, H.C. (1999): Reversible $\mathrm{Ca}$ gradients between the subplasmalemma and cytosol differentially activate $\mathrm{Ca}$ dependent $\mathrm{Cl}$ currents. J. Gen. Physiol. 113:249-266.

Miledi, R. and Parker, I. (1984): Chloride current induced by injection of calcium into Xenopus oocytes. J. Physiol. 357, 173-183.

Minke, B. (1977):Drosophila mutant with a transducer defect. Biophys.Struct. Mech. 3, 59-64.

Montell, C. (1997): New light on TRP and TRPL. Mol. Pharmacol. 52, 755-763.

Montell, C. (2005):Drosophila TRP channels. Eur. J. Physiol. 451, 19-28.

Mundy, G.R. and Guise, T.A. (1999): Hormonal control of calcium homeostasis. Clin. Chem. $45,1347-1352$.

Nilius, B. and Owsianik, G. (2011): The transient receptor potential family of ion channels. Genome Biol. 12, 218-228.

O'Keeffe, B.A.; Cilia, S.;Maiyar, A.C.;Vaysberg, M. and Firestone, G.L. (2013):The serum- and glucocorticoid-induced protein kinase-1 (Sgk1) mitochondria connection: identification of the IF-1 inhibitor of the $F(1) F(0)$-ATPase as a mitochondria-specific binding target and the stress-induced mitochondrial localization of endogenous Sgk-1. Biochimie. 95, 1258-1265.

Orrenius, S.;Zhivotovsky, B. and Nicotera, P. (2003): Regulation of cell death. The calciumapoptosis link. Nat. Rev. Mol. Cell. Biol. 4, 552-565.

Palmada, M.; Poppendieck, S.; Embark, H.M.; van de Graaf, S.F.; Boehmer, C.; Bindels, R.J. and Lang, F. (2005):Requirement of PDZ domains for the stimulation of the epithelial $\mathrm{Ca}^{2+}$ channel TRPV5 by the NHE regulating factor NHERF2 and the serum and glucocorticoid inducible kinase SGK1. Cell. Physiol. Biochem. 15, 175-182.

Parekh, A.B.and Penner, R. (1997): Store depletion and calcium influx. Physiol Rev. 77, 901-30.

Peacock, M. (2010): Calcium metabolism in health and disease. Clin. J. Am. Soc. Nephrol. 5, S2330 .

Putney, J.W. (1990):Capacitative calcium entry revisited. Cell Calcium. 11, 611-624.

Riccio, A.;Medhurst, A.D.;Mattei, C.;Kelsell, R.E.;Calver, A.R.; Randall, A.D.;Benham, C.D. and Pangalos, M.N. (2002): mRNA distribution analysis of human TRPC family in CNS and peripheral tissues. Brain Res Mol Brain Res. 109, 95-104.

Sinkins, W.G.;Goel, M.;Estacion, M. and Schilling, W.P. (2004): Association of immunophilinswith mammalian TRPC channels. J Biol Chem. 279, 34521-34529. 
Sobiesiak, M.;Shumilina, E.; Lam, R.S.;Wölbing, F.;Matzner, $\quad$ N.;Kaesler, S.;Zemtsova, I.M.;Lupescu, A.;Zahir, N.;Kuhl, D.; Schaller, M.;Biedermann, T. and Lang, F. (2009): Impaired mast cell activation in gene-targeted mice lacking the serum- and glucocorticoidinducible kinase SGK1. J. Immunol. 183, 4395-4402.

Sopjani, M.; Kunert, A.; Czarkowski, K.; Klaus, F.; Laufer, J.; Foller, $M$. and Lang, $F$. (2010):Regulation of the $\mathrm{Ca}^{2+}$ channel TRPV6 by the kinases SGK1, PKB/Akt, and PIKfyve. J. Membr. Biol. 233, 35-41.

Taruno, A.;Niisato, N. and Marunaka, Y. (2008): Intracellular calcium plays a role as the second messenger of hypotonic stress in gene regulation of SGK1 and $\mathrm{ENaC}$ in renal epithelial A6 cells. Am. J. Physiol. Renal Physiol. 294, F177-F186

Vazquez, G.; Wedel, B.J.; Aziz, O.;Trebak, M. and Putney, J.W. (2004): The mammalian TRPC cation channels. Biochim.Biophys.Acta. Mol. Cell. Res. 1742, 21-36.

Verkhratsky, A. and Petersen, O.H. (2002): The endoplasmic reticulum as an integrating signalling organelle: from neuronal signalling to neuronal death. Eur. J. Pharmacol. 447, 141-154.

Wagner, C.A.; Friedrich, B.;Setiawan, I.; Lang, F. and Broer, S. (2000): The use of Xenopuslaevis oocytes for the functional characterization of heterologously expressed membrane proteins. Cell. Physiol. Biochem. 10, 1-12.

Waldegger, S.; Barth, P.;Raber, G. and Lang, F. (1997): Cloning and characterization of a putative human serine/threonine protein kinase transcriptionally modified during anisotonic and isotonic alterations of cell volume. Proc. Natl. Acad. Sci. 94, 4440-4445.

Webster, M.K.; Goya, L.;Ge, Y.;Maiyar, A.C. and Firestone, G.L. (1993): Characterization of $\mathrm{sgk}$, a novel member of the serine/threonine protein kinase gene family which is transcriptionally induced by glucocorticoids and serum. Mol. Cell. Biol. 13, 2031-2040.
Wesch, D.; Miranda, P.;Afonso-Oramas, D.;Althaus, M.; Castro-Herna'ndez, J.; Dominguez, J.;Morty, R.E.;Clauss, W.;Gonza'lezHernández, T.;Alvarezde la Rosa, D. and Giraldez, T. (2010): The neuronal-specific SGK1.1 kinase regulates $\{$ delta $\}$-epithelial $\mathrm{Na}$ channel independently of PY motifs and couples it to phospholipase $\mathrm{C}$ signaling. Am. J. Physiol. Cell. Physiol. 299, C779-C790.

Yun, C.C.; Chen, Y. and Lang, F. (2002a): Glucocorticoid activation of $\mathrm{Na}^{+} / \mathrm{H}^{+}$exchanger isoform 3 revisited. The roles of SGK1 and NHERF2.J. Biol. Chem. 277, 7676-7683.

Yun, C.C.;Palmada, M.; Embark, H.M.;Fedorenko, O.;Feng, Y.; Henke, G.;Setiawan, I.;Boehmer, C.;Weinman, E.J.;Sandrasagra, S.;Korbmacher, C.; Cohen, P.; Pearce, D. and Lang, F. (2002b):The Serum and Glucocorticoid-Inducible Kinase SGK1 and the $\mathrm{Na}^{+} / \mathrm{H}^{+}$Exchange Regulating Factor NHERF2 Synergize to Stimulate the Renal Outer Medullary $\mathrm{K}^{+}$Channel ROMK1. J. Am. Soc. Nephrol. 13, 2823-2830.

Zhang, C.; Miller, C.L.; Brown, E.M. and Yang, J.J. (2015): The calcium sensing receptor: from calcium sensing to signaling. Sci. China Life Sci., 58, 14-27.

Zhou, R. and Snyder, P.M. (2005): Nedd4-2 phosphorylation induces serum and glucocorticoid-regulated kinase (SGK) ubiquitination and degradation. J. Biol. Chem. 280, 4518-4523.

Zhu, X.; Jiang, $M$. and Birnbaumer, $L$. (1998):Receptor-activated Ca2+ influx via human Trp3 stably expressed in human embryonic kidney (HEK)293 cells. Evidence for a non-capacitative $\mathrm{Ca} 2+$ entry.J. Biol. Chem. 273, 133-42.

Zhu, X.;Meisheng, J.; Peyton, M.;Boulay, G.; Hurst, R.; Stefani, E. and Birnbaumer, $L$. (1996):TRP, a novel mammalian gene family essential for agonist-activated capacitative $\mathrm{Ca}^{2+}$ entry. Cell. 85, 661-671.

Zweifach, A. and Lewis, R.S. (1995): Rapid inactivation of depletion-activated calcium current (ICRAC) due to local calcium feedback. J. Gen. Physiol., 105, 209-226. 


\section{تنظيم القتاة المحتملة القصيرة ب للمستقبلات العابرة في الإنسان بواسطة إنزيم الكيناز المحدث

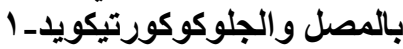 \\ حسدي أمبارك}

Assiut University web-site: www.aun.edu.eg

يتم التعبير على نطاق واسع عن القنوات المحتملة للمستقبلات العابرة (قنواتTRP) في عدد كبير من مختلف أنو اع اعلى الخلايا البشرية

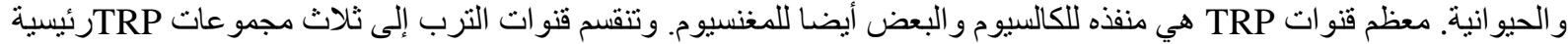

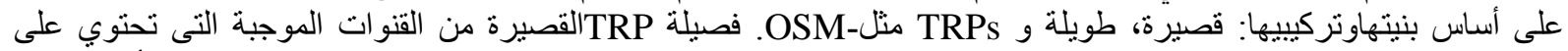

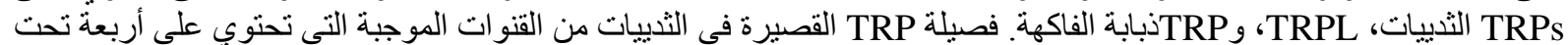

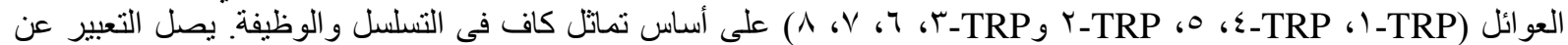

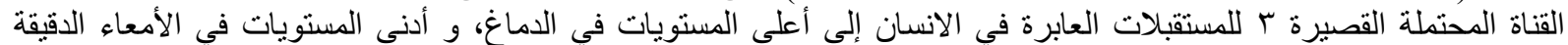

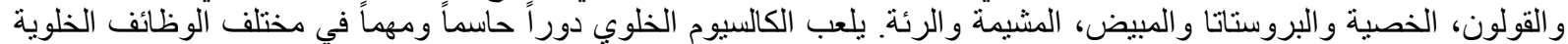

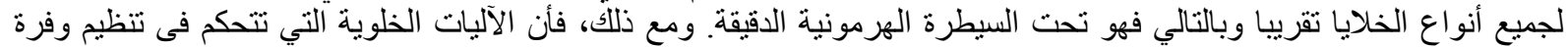

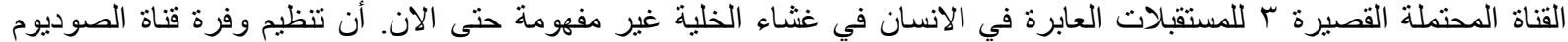

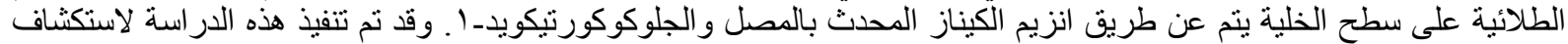

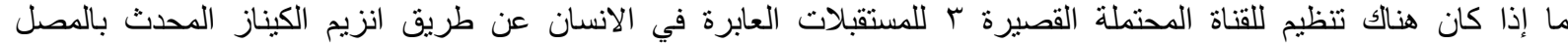

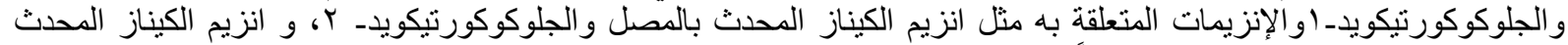

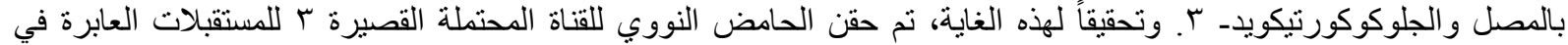

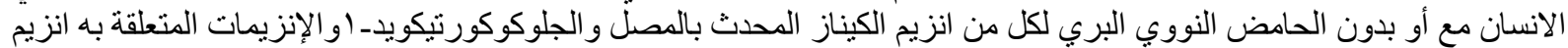

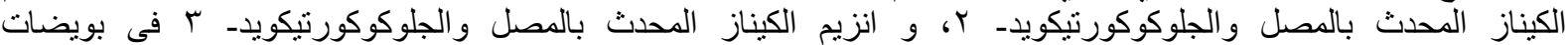

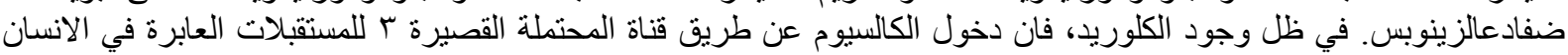

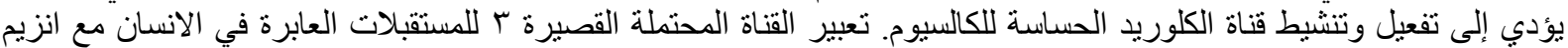

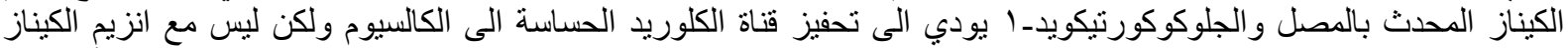

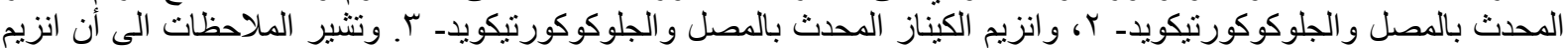

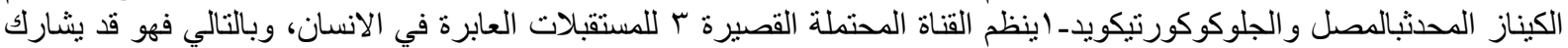

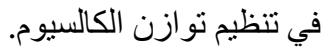

